\title{
Soluble Transferrin Receptor Levels of Apparently Healthy Adults in Port Harcourt, Nigeria
}

\author{
Chilota Chibuife Efobi ${ }^{1 *}$, Benedict Nwogo ${ }^{2}$, Igwebuike Victor Onyiaorah ${ }^{3}$ and Oseikhuemen Adebayo Ejele ${ }^{4}$ \\ ${ }^{1}$ Department of Haematology, Chukwuemeka Odumegwu Ojukwu University, Akwa Campus, Awka, Anambra State, Nigeria. \\ ${ }^{2}$ Department of Haematology, University of Benin, Benin city, Edo State \\ ${ }^{3}$ Department of Histopathology, Nnamdi Azikiwe University, Nnewi Campus, Nnewi, Anambra State \\ ${ }^{4}$ Department of Haematology, University Of Port Harcourt, Port Harcourt, Rivers State.
}

\begin{abstract}
Background: soluble transferrin receptor is an early marker of tissue iron deficiency before onset of anaemia. sTfR is one of the diagnostic markers for iron deficiency anaemia. Iron deficiency anaemia is one of the most prevalent causes of anaemia in our environment. However, there is no established reference range for this diagnostic marker sTfR in our environment.

Objectives: To determine the soluble transferrin receptor levels in apparently normal adults in Port Harcourt Nigeria, determine the reference value of sTfR in the study population.

Methods: This is a descriptive cross sectional study conducted at the university of Port Harcourt Teaching Hospital. One hundred and fiftyparticipants who satisfied the inclusion criteria were enrolled for this study. Full blood count and sTfR concentration were assayed on anticoagulated blood samples using a 3-part auto analyzer (Sysmex -KX2IN®) and Human sTfR ELISA kit by BioVendor respectively. The results were analysed using SPSS version 21. P value $<0.05$ was considered significant.
\end{abstract}

Results: The mean sTfR concentration of the study population was $0.89 \pm 0.46 \mathrm{ug} / \mathrm{mL}$ with a range of $0.3-3.05 \mathrm{ug} / \mathrm{ml}$. The mean value of sTfR for males and females were $0.92 \pm 0.49 \mathrm{ug} / \mathrm{ml}$ and $0.82 \pm 0.37 \mathrm{ug} / \mathrm{ml}$ and the mean sTfR levels did not differ significantly for age and sex.

Conclusion: The reference value of sTfR concentration in healthy adults in Port Harcourt was established as 0.3-3.05ug/ml. This study found no statistically significant relationship of sTfR between the different sexes and ages.

\section{Keywords: sTfR, Healthy Adults, Screening Tool, Iron Deficiency}

\section{Introduction}

Iron deficiency anaemia (IDA) is the most common anaemia in the world despite abundance of iron in the environment. The examination of bone marrow aspirate, stained with Prussian blue stain for iron, is still considered as the best method for evaluating iron status in patients with indeterminate laboratory findings. Its draw backs are that it is invasive, expensive, the results may be operator dependent and the aspirate obtained may not be adequate. It has also been shown to be uncomfortable and therefore not practical for routine use. ${ }^{[1,2]}$ Due to the high global burden of iron deficiency anemia which has made it a public health issue, there is a need to devise a screening tool that can be used to detect iron deficiency before onset of anemia to aid early intervention and reduce the mortality and morbidity associated with IDA. This necessitates the need for a less invasive, specific and sensitive means of detecting tissue iron deficiency before onset of anemia. Soluble transferrin receptor (sTfR) assay is a feasible option. ${ }^{[3]}$

Transferrin receptors are expressed on all dividing cells and its rate of synthesis is related to the cell's iron requirement. ${ }^{[4]}$ There are are up to $10,000-100,000 \mathrm{sTFr}$ molecules per cell in actively dividing cells especially in erythroid precursors in the bone marrow and placental syncythiotrophoblast. sTfR concentration increases up to two folds in iron deficiency, making it an important tool for detecting early tissue iron deficiency before onset of anaemia. The other assays for determining iron deficiency, like serum iron, ferritin, total iron binding capacity, etc, are affected by inflammatory changes. ${ }^{[5]}$ sTfR is not affected by inflammationmaking it superior to these other assays. ${ }^{[6,7]}$ Sweet et al reported that sTfR measurement could replace other assays for iron deficiency state especially in subclinical iron deficiency present in their study population which was undetected by these other assays. ${ }^{[8]}$

There is no difference between sTfR concentrations in healthy males and females, ${ }^{[9,10]}$ but the values are higher in children compared to adults. ${ }^{[1]}$ However, Blacks have a higher sTfR concentration than non- blacks. ${ }^{[12]}$ This difference may be related to the well-known but unexplained difference in haemoglobin concentrations in Blacks and Caucasians.Therefore, misdiagnosis of 
iron deficiency can result if Caucasian values are used for blacks.

Some studies have also shown that sTfR is increased in blood donors, ${ }^{[13]}$ during physical exercise, ${ }^{[14},{ }^{15]}$ cigarette smoking, ${ }^{[8]}$ and high altitude, ${ }^{[16]}$ where reduced oxygen tension necessitates increased erythropoiesisbut is reduced by ascorbic acid administration and iron supplementation. ${ }^{[17,18]}$

A blood donor loses about 200- $250 \mathrm{mg}$ of iron with every unit of $450 \mathrm{mls}$ of blood donated. Some blood donors, especially commercial donors might donate more than three times a year for financial reasons, putting more pressure on their iron stores.

Several studies have provided reference ranges for soluble transferrin receptor concentration in the white population. There is paucity of studies on sTfR in our environment hence this study was aimed to determine reference value of sTfR in our environment.

A study done in the United States of America showed that the reference range of sTfR receptor is $10.3-29.1 \mathrm{nmol} / 1$.

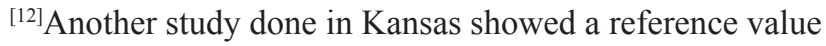
of $2.8-8.5 \mathrm{mg} / 1,{ }^{[19]}$ while one done on Arabs in the Sultanate of Oman showed a reference value of $10.7-38.7 \mathrm{nmol} / 1,^{[20]}$ while another study showed $2.9-8.3 \mathrm{mg} / 1 .^{[21]}$

The reference interval of serum transferrin receptor varies between different assay systems, depending on the choice of calibrators.It was proposed that recombinant serum transferrin receptor (rsTfR) preparation 07/202, may be designated a WHO Reference Reagent with assigned values of $21.7 \mathrm{mg} / \mathrm{L}$ and $30.3 \mathrm{nmol} / \mathrm{L}$ (when reconstituted with $0.50 \mathrm{~mL}$ distilled or deionized water). ${ }^{[22]}$

\section{Patients and Methods}

Study Design and Source: This is a descriptive study done at the University of Port Harcourt Teaching Hospital (UPTH), Rivers State, Nigeria, from September 2013 to November 2013.

Study Population: A total of 150 participants, healthy non- fasting, males and females, within the age range of 17- 60 years were selected by simple random sampling method. A research questionnaire was used to obtain basic information from participants including age, sex, tribe, occupation, level of education, history of chronic illness, nutritional history, history of smoking, menopausal status, blood donation history. Blood samples were collected afterwards for determination of full blood count and sTfR levels.
Three milliliters of venous blood was collected by venipuncture into ethylene diamine tetra-acetic acid (EDTA) bottles for each participant. Samples to be analyzed for full blood count were run immediately. Plasma samples were obtained after centrifugation of anticoagulated blood at 2500 revolutions per minute for 2 minutes. Plasma samples of subjects that met the FBC inclusion criteria and were then stored at a temperature of $-70^{\circ} \mathrm{C}$. The full blood count was performed using 3 part autoanalyser (Sysmex $-\mathrm{KX} 2 \mathrm{IN}^{\circledR}$ ).

Soluble transferrin receptor concentration was determined by an enzyme immunoassay (EIA) monoclonal antibody technique using Human sTfR ELISA kit (BioVendor $^{\circledR}$ Research and Diagnostic Products D-69120 Heidleberg Germany). LOT- E13-012.

Inclusion criteria: PCV for healthy males $=39-50 \%$, (haemoglobin concentration $=13.0-16.5 \mathrm{~g} / \mathrm{dL}$ ) and normal reference valve for PCV for healthy females $=33-40 \%$ (haemoglobin concentration $=12.0-15.0 \mathrm{~g} / \mathrm{dL}$ ). ${ }^{[23]} \mathrm{The}$ total white cell count was $2.5 \times 10^{9} / \mathrm{L}-11 \times 10^{9} / \mathrm{L}$. MCV, MCH and $\mathrm{MCHC}$ were $80.0-92.0 \mathrm{fL}, 24.6-30.2 \mathrm{pg}, 31.2-34.6 \mathrm{~g} /$ $\mathrm{dL}$ respectively. Platelet count was $90-350 \times 10^{9} / 1$. Subjects with values outside these ranges were excluded.

Excluded were subjects with febrile illness within 4 weeks prior to the study, pregnant and presently menstruating females, persons on iron supplements 3 months prior to study, subjects with haematological parameters outside the ranges stated above.

Ethical Considerations: Ethical approval was obtained from the Research Ethical Committee of University of Port Harcourt Teaching Hospital (UPTH). A signed consent form was obtained from each participant before recruitment.

Statistical Analysis: Data was analyzed using SPSS 21.0. Descriptive statistics such as means and standard deviations were calculated for quantitative variables like haematological indices. Tables were generated according to objectives. Statistical tools such as students t test, analysis of variances (ANOVA), were used as appropriate to make statistical inferences about population parameters. Pearson's correlation test was employed to determine the strength of association between haematological indices and sTfR levels. A p-value of $<0.05$ was considered statistically significant.

\section{Results}

Demographics A total of 150 respondents participated in the study consisting of 107 (71.3\%)males and 43(28.7\%) females. The ages of the respondents were grouped as: 
21-30 which had 42 respondents(28.0\%), 31-40 had 75 respondents(50\%), 41- 50 had 28 respondents(18.7), 51-60 had 5 respondents(3.3\%). Thirty six out of the 43 females were premenopausal, while 7 were postmenopausal. Majority of the respondents $(64 \%)$ came from the southsouth geopolitical region. Details of general characteristics of the study is shown in table 1 .

Haematological Parameters: The mean PCV of the study population was $44.15 \% \pm 3.96$. The mean PCV for males was significantly higher than that of females $45.79 \pm 3.06$ vs $40.06 \% \pm 2.84 ; p<0.001$. The mean haemoglobin concentration of the study population was $14.18 \pm 1.38 \mathrm{~g}$ / $\mathrm{dL}$. The mean haemoglobin for males and females were $14.75 \pm 1.03 \mathrm{~g} / \mathrm{dL}$ and $14.05 \pm 1.60 \mathrm{~g} / \mathrm{dL}$ respectively $\mathrm{p}$ value $=<0.001$.

The mean $\mathrm{MCV}, \mathrm{MCH}, \mathrm{MCHC}$ of the study population were $93.11 \pm 3.44 \mathrm{fl}, 29.84 \pm 0.06 \mathrm{pg}$ and $32.09 \pm 0.87 \mathrm{~g} /$ $\mathrm{dL}$ respectively. No statistically significant difference was found in red cell indices of males and females. The difference in the total white cell and platelet counts of males and females were statistically significant. Details are shown in table 2.

Soluble Transferrin Receptor Levels: The total mean value of soluble transferrin receptor in the study population was $0.89 \pm 0.46 \mathrm{ug} / \mathrm{ml}$, with a range of $0.3-3.05 \mathrm{ug} / \mathrm{ml}$. Males had a higher sTfR level than females $0.92 \pm 0.49 \mathrm{ug} / \mathrm{ml}$ vs $0.82 \pm 0.37 \mathrm{ug} / \mathrm{ml}$. however, the difference in the mean is not statistically significant $(\mathrm{p}$ value $=0.204)$ as shown in table

Table 1: Sociodemographic Variables

\begin{tabular}{|c|c|c|}
\hline \multicolumn{2}{|c|}{ Variables } & \multirow{2}{*}{$\begin{array}{c}\text { Frequency }(\%) \mathbf{N}=150 \\
42(28.0)\end{array}$} \\
\hline \multirow{4}{*}{ Age group(years) } & $21-30$ & \\
\hline & $31-40$ & $75(50.0)$ \\
\hline & $41-50$ & $28(18.7)$ \\
\hline & $51-60$ & $5(3.3)$ \\
\hline \multirow{4}{*}{ Sex } & Males & $107(71.3)$ \\
\hline & Females & $43(28.7)$ \\
\hline & Premenopausal & $36(24.0)$ \\
\hline & Postmenopausal & $7(4.7)$ \\
\hline \multirow{3}{*}{ Regions } & South South & $96(64.0)$ \\
\hline & South East & $47(31.3)$ \\
\hline & Others & $7(4.7)$ \\
\hline \multirow{3}{*}{ Level of Education } & Primary & $4(2.7)$ \\
\hline & Secondary & $13(8.7)$ \\
\hline & Tertiary & $133(88.7)$ \\
\hline \multirow{4}{*}{ Occupation } & Civil servants & $31(20.7)$ \\
\hline & Healthcare Professionals & $85(56.7)$ \\
\hline & Students & $19(12.7)$ \\
\hline & Others & $15(10.0)$ \\
\hline
\end{tabular}

Key: $N$ indicates number of variables
3. There was no significant difference of sTfR amongst different age groups.

The mean sTfR levels of male and female participants for various age groups is shown in table 3. For those in the age range of $21-30 \mathrm{yrs}$, sTfR was $0.88 \pm 0.48 \mathrm{ug} / \mathrm{dl}$ and $0.80 \pm 0.47 \mathrm{ug} / \mathrm{dl}$ for males and females respectively and for those aged $51-60,0.98 \pm 0.53 \mathrm{ug} / \mathrm{dl}$ and $0.97 \pm 0.13 \mathrm{ug} / \mathrm{dl}$ for males and females respectively. The difference in mean STfR across the various age groups were not statistically significant.

sTfR Levels and Menopausal Status: Most of the participants of this study were males 107 (71.3) with a mean sTfR of $0.92 \pm 0.49 \mathrm{ug} / \mathrm{dl}$. The females comprised $28.7 \%$ of the participants. Majority of the females were premenopausal 36 (24.0), while $4.7 \%$ of them were postmenopausal. The mean sTfR levels of females was $0.82 \pm 0.37 \mathrm{ug} / \mathrm{dl}$. The sTfR level did not differ significantly between pre and post -menopausal women in the study population as seen in table 4 .

Correlation Between sTfR and Haematological Parameters: There was a weak positive correlation between sTfR concentration and some haematological parameters in the study group. The $r$ values for $\mathrm{PCV}$, $\mathrm{Hb}$, WBC, Platelet, and MCHC were: 0.033, 0.032, $0.093,0.092$, and 0.002 respectively but these were not statistically significant. Aweak negative correlation was observed between MCV and MCH with sTfR r= -0.042 and -0.035 respectively which were not statistically significant as shown in table 5. 
Table 2: Stfr and Haematological Parameters in the Study Population.

\begin{tabular}{|c|c|c|c|c|c|}
\hline Variables & $\begin{array}{c}\text { Total Mean } \pm \text { SD } \\
\qquad N=150\end{array}$ & $\begin{array}{l}\text { Male Mean } \pm \text { SD } \\
\qquad N=107\end{array}$ & $\begin{array}{l}\text { Female Mean } \pm S D \\
\qquad N=43\end{array}$ & $\mathbf{t}$ & P Value \\
\hline sTfR (ug/ml) & $0.89 \pm 0.46$ & $0.92 \pm 0.49$ & $0.82 \pm 0.37$ & 1.275 & 0.204 \\
\hline PCV (\%) & $44.15 \pm 3.96$ & $45.79 \pm 3.06$ & $40.06 \pm 2.84$ & 10.576 & $<0.001$ \\
\hline $\mathrm{Hb}(\mathrm{g} / \mathrm{dl})$ & $14.18 \pm 1.38$ & $14.75 \pm 1.03$ & $12.75 \pm 1.06$ & 10.725 & $<0.001$ \\
\hline WBC $\left(\times 10^{9} / I\right)$ & $7.40 \pm 1.56$ & $7.21 \pm 1.52$ & $7.86 \pm 1.57$ & -2.334 & 0.021 \\
\hline PLATELET(x109/I) & $241.77 \pm 45.76$ & $233.31 \pm 43.16$ & $262.81 \pm 45.74$ & -3.722 & $<0.001$ \\
\hline MCV(femtolitres) & $93.11 \pm 3.44$ & $92.83 \pm 3.26$ & $93.82 \pm 3.82$ & -1.608 & 0.110 \\
\hline MCH(picograms) & $29.84 \pm 0.06$ & $29.87 \pm 0.73$ & $29.80 \pm 0.91$ & 0.516 & 0.607 \\
\hline $\mathrm{MCHC}(\mathrm{g} / \mathrm{dl})$ & $32.09 \pm 0.87$ & $32.22 \pm 0.87$ & $31.79 \pm 0.80$ & 2.794 & 0.006 \\
\hline
\end{tabular}

Key: SD- standard deviation. $N$-number of variables. sTfR-soluble transferrin receptor. PCV-packed cell volume. Hb-haemoglobin. WBC-white blood cells. $M C V$ - mean cell volume. MCH- mean cell haemoglobin. MCHC- mean cell haemoglobin concentration.

Table 3: Stfr Levels by Age Group and Sex of the Study Population.

\begin{tabular}{|c|c|c|c|c|c|}
\hline Age groups & Sex & FREQUENCY(\%) & Mean \pm SD & $\mathbf{t}$ & P Value \\
\hline \multirow{2}{*}{$21-30 y r s$} & Male & $33(22.0)$ & $0.88 \pm 0.48$ & \multirow{2}{*}{0.428} & \multirow{2}{*}{0.671} \\
\hline & Female & $9(6.0)$ & $0.80 \pm 0.47$ & & \\
\hline \multirow{2}{*}{$31-40 y r s$} & Male & $52(34.7)$ & $0.94 \pm 0.52$ & \multirow{2}{*}{1.272} & \multirow{2}{*}{0.207} \\
\hline & Female & $23(15.3)$ & $0.79 \pm 0.33$ & & \\
\hline \multirow{2}{*}{$41-50 y r s$} & Male & $20(13.4)$ & $0.95 \pm 0.43$ & \multirow{2}{*}{0.478} & \multirow{2}{*}{0.636} \\
\hline & Female & $8(5.3)$ & $0.86 \pm 0.45$ & & \\
\hline \multirow{2}{*}{$51-60 y r s$} & Male & $2(1.3)$ & $0.98 \pm 0.53$ & \multirow{2}{*}{0.028} & \multirow{2}{*}{0.979} \\
\hline & Female & $3(2.0)$ & $0.97 \pm 0.13$ & & \\
\hline
\end{tabular}

Key: $N=$ number of participants, $S D$ - standard deviation, $s T f R$ unit $=u g / m l$

Table 4: Stfr Levels by Sex and Menopausal Status

\begin{tabular}{|l|c|c|c|c|}
\hline Sex & Frequency (\%) & Mean \pm SD (ug/ml) & t value \\
\hline Males & $107(71.3)$ & $0.92 \pm 0.49$ & 1.275 & 0.204 \\
\hline Females & $43(28.7)$ & $0.82 \pm 0.37$ & & \\
\hline Premenopausal & $36(24.0)$ & $0.82 \pm 0.39$ & 0.758 & 0.470 \\
\hline Postmenopausal & $7(4.7)$ & $0.86 \pm 0.20$ & \\
\hline
\end{tabular}

Table 5: Correlation Between Stfr and Haematological Parameters in the Study Participants

\begin{tabular}{|l|c|c|c|c|c|c|c|c|}
\hline & & PCV (\%) & HB (g/dl) & WBCx10 $/ /$ & PLTx10 $/ I$ & MCV(fl) & MCH(pg) & MCHC(g/dl) \\
\hline STFR(ug/ml) & R & 0.033 & 0.032 & 0.093 & 0.092 & -0.042 & -0.035 & 0.002 \\
\hline & P value & 0.691 & 0.701 & 0.259 & 0.263 & 0.608 & 0.671 & 0.984 \\
\hline
\end{tabular}

Key: SD-standard deviation. sTfR-soluble transferrin receptor. PCV-packed cell volume. Hb- haemoglobin.WBC-white blood cell count. MCV-mean cell volume. $\mathrm{MCH}$ - mean cell haemoglobin. MCHC-mean cell haemoglobin concentration.

\section{Discussion}

Various authors have reported varying reference values for sTfR depending on the study population. This study on apparently healthy Nigerians found the reference range of sTfR to be $0.3-3.05 \mathrm{ug} / \mathrm{ml}$. The upper limit is higher than those reported in some non-African based studies. ${ }^{[12,20,24]}$ Van den Bosch $G$ et al ${ }^{[24]}$ Allen J et al and KnoxMaculay et al reported ${ }^{[12,20]}$ reference values of 0.58 $2.50 \mathrm{mg} / 1,0.76-2.77 \mathrm{mg} / 1,0.5-2.7 \mathrm{mg} / 1$ respectively.
Similarly the reference range of the study population is higher than that of the Biovendor ELISA kit used for the study, which was $0.378-1.513 \mathrm{ug} / \mathrm{ml} .{ }^{[25]}$ The mean sTfR in our study was $0.89 \pm 0.46 \mathrm{ug} / \mathrm{mL}$. Kohgo et al, ${ }^{[9]}$ Van den Bosch $\mathrm{G}$ et al ${ }^{[24]}$ reported lower values of $0.253 \pm 0.08 \mathrm{ug} /$ $\mathrm{ml}$ and $0.58 \pm 0.26 \mathrm{mg} / 1$ respectively. Allen and KnoxMacaulay obtained a marginally higher mean in their studies of $1.4 \pm 0.3 \mathrm{mg} / 1$ and $1.5 \pm 0.5 \mathrm{mg} / 1$ respectively. Similarly, Simek M and his colleagues in another related study found mean values higher than that reported in the 
index study which was $1.84 \pm 0.8 \mathrm{mg} / 1 .{ }^{[26]}$ Flowers and his colleagues ${ }^{[10]}$ reported the sTfR value from their study to be 4.21-7.05mg/l, while Erhardt and his friends reported their own values to be $2.9-8.3 \mathrm{mg} / 1 .{ }^{[21]}$ These values are many folds higher than what we reported in our study, suggesting that there are variations in sTfR levels from one population to another. These variations might be due to environmental, racial, dietary and genetic factors and also assay methods used.

The sTfR levels did not differ with age. $(\mathrm{F}=0.160, \mathrm{p}=$ 0.923 ) Von Schmiesing et $\mathrm{al}^{[27]}$ in a similar study which though found relatively higher ranges for each age group when compared to the index study, did not also observe any significant difference in the mean sTfR across the various age groups which is similar to our observations in this study. This was affirmed by Raya et al ${ }^{[28]}$ and other authors. $[10,11,19,24,29]$ This is probably because the study population, being all adults, have all attained adult levels of sTfR. Contrary to this, Jong Weon Choi et al ${ }^{[30]}$ observed age related differences in sTfR levels. This difference might be due to the fact that the study participants used by Jong Weon Choi and his friends were not limited to adults alone, unlike our study and other studies. ${ }^{[10,11,19,24]}$

We observed that the mean sTfR levels for both sexes were not significantly different though males had a slightly higher mean sTfR. Kohgo et al and Allen et a ${ }^{[9,12]}$ in their respective study, even though the former reported lower values and the latter higher sTfR values for each sex, did not find any significant difference in their mean sTfR as also seen in other related studies. ${ }^{[31,32]}$. On the contrary Knox- macaulay and co suggested otherwise from their work, stating that there was a statistically significant difference of sTfR values in men and women. ${ }^{[20]}$ Another study also noted a higher sTfR levels in females compared to males. ${ }^{[29]}$ The reason for these differences cannot be readily explained, however, this might require confirmation using a larger study population. There was no significant difference in STfR with pre and postmenopausal women ( $. \mathrm{P}=0.470)$,suggesting that menstrual blood loss of iron does not significantly affect sTfR levels in normal adults. This observation was affirmed by Allen and his colleagues. ${ }^{[12]}$

\section{Conclusion:}

This study using immunological assay has established reference range forsTfR to be $0.3-3.05 \mathrm{ug} / \mathrm{ml}$ in heathy adult population in Port Harcourt Nigeria.sTfR did not differ significantly across various age groups and between males and females. Menstrual status in healthy females did not significantly impact on the sTfR level.

\section{Acknowledgements}

We are grateful to our supervisor and teacher, Prof O.A Ejele for his tutelage, advice and input in the course of this study. We thank Prof C.A Nwauche for his advice and encouragement. We also acknowledge Dr (Mrs) E.E Igbigbi, our Head of Department for all her support. We thank Mr Ben Alime for his assistance in the technical aspects of this study.

Finally, we thank our families for their sacrifice, patience and understanding.

\section{References}

1. Koulaouzidis A, Said E, Cottier R, Saeed A. Soluble transferrin receptor and iron deficiency, a step beyond ferritin. A systematic review. J Gastrointestin Liver Dis. 2009; 18(3): 345-352

2. Krause JR, Stolc V. Serum ferritin and bone marrow iron stores. Correlation with absence of iron in biopsy specimens. Am J Clin Pathol. 1979; 72: 817-820.

3. Jayarane S SP. Serum soluble transferrin receptor in hypochromic microcytic anemia. Singapore Med J. 2006; 47(60): 3-7.

4. Speeckaert MM, Speeckaert R, Delanghe JR. Biological and clinical aspects of soluble transferrin receptor.Crit Rev Clin Lab Sci. 2010; 47(5-6):213-28

5. Ejaz H, Muhammad A, Masood A, Waqar A MB. Evaluation of serum transferrin receptor in diagnosing and differentiating iron deficiency anemia from anemia of chronic disorders. JPMA. 2005; 55(13): 5-8

6. Jain S, Narayan S, Chandra J, Sharma S, Malhan P. Evaluation of serum transferrin receptor and sTfR ferritin indices in diagnosing and differentiating iron deficiency anemia from anemia of chronic disease. Indian $\mathrm{J}$ of Paediatr. 2010; 77(2): 179-83.

7. Chua E, Clague JE, Sharma Ak, Horan MA, Lombard M. serum transferrin receptor assay in iron deficiency anemia and anemia of chronic disease in the elderly. G J Med. 1999; 92:587-94.

8. Sweet DG, Savage G, Tubman TR, Lappin TR, Halliday HL. Study of maternal influences on fetal iron status at term using cord blood transferrin receptors. Arch Dis Child Fetal Neonatal Ed.2001;84(1):F40-3.

9. Kohgo Y, Niitsu Y, Kondo H, Kato J, Tsushima N, Sasaki $\mathrm{K}$, et al. Serum transferrin receptor as a new index of erythropoiesis. Blood. 1987; 70(6): 1955-8.

10. Flowers CH, Skikne BS, Covell AM, Cook JD. The clinical measurement of serum transferrin receptor. The J Lab Clin Med. 1989; 114(4): 368-77.

11. Virtanen MA, Viinikka LU, Virtanen MK, Svahn JC, Anttila RM, Krusius T et al. higher concentrations of serum transferrin in children than in adults. Am J Clin Nutr. 1999; 69:256-60 
12. Allen J, Backstrom KR, Cooper JA et al. Measurement of soluble transferrin receptor in serum of healthy adults. Clin Chem. 1998; 44(1): 35-9.

13. Szymczyk-Nuzka M, Wolowiec D. Iron stores in regular blood donors. Polskie Archiwum Medycyny Wewnetrznej. 2003; 110(6): 1415- 21.

14. Schumacher YO, Schmid A, Konig D, Berg A. effects of exercise on soluble transferrin receptor and other variables of iron status. Br J Sports Med. 2002; 36(3): 195-9.

15. Malczewska-Lenczowska J, Stupnicki R, Gabryś T. Effects of exercise on markers of iron status in serum of crosscountry skiers. Biol. Sport. 2010; 29(4): 241-7.

16. Cook JD, Boy E, Flowers C, Daroca MDC. The influence of high-altitude living on body iron. Blood.2005; 106(4):1441-6

17. Tarng D-C, Hung S-C, Huang T-P. Effect of intravenous ascorbic acid medication on serum transferrin receptor in hemodialysis patients. J Am Soc of Nephrol. 2004;15(9):2486-93.

18. Zhu Yi, Haas JD. Response of serum transferrin receptor to iron supplementation in iron-depleted non-anaemic women 1-3. Am J Clin Nutr. 1998; 67:271-5

19. Skikne BS, Flowers CH, Cook JD. Serum transferrin receptor. A quantitative measure of tissue iron deficiency. Blood. 1990; 75(9): 1870-6.

20. Knox-macaulay H, Gravell D, Elender F. Serum Transferrin Receptor Status of Healthy Adult Arabs. Ann Clin Lab Sci. 2007;37(1):57-62.

21. Erhardt JG, Estes JE, Pfeiffer CM, Biesalski HK, Craft NE. combined measurement of ferritin, soluble transferrin receptor, retinol binding protein ad $\mathrm{C}$ - reactive protein by an inexpensive, sensitive and simple sandwich enzyme- linked immunosorbent assay technique. J Nutr. 2004; 134(11): 3127-3132.

22. Thorpe SJ, Heath A, Sharp G, Cook J, Ellis R, Worwood M. A WHO reference reagent for the Serum Transferrin Receptor (sTfR): international collaborative study to evaluate a recombinant soluble transferrin receptor preparation. Clin Chem Lab Med. 2010 Jun;48(6):815-20

23. Umeh SO, Emelugo BN. A Survey Of Normal Haematological Variables Among Adults In Nigeria As Seen In Anambra State. Trop J Med Res.2008; 12 (1): 29-31.

24. Van den Bossche .G, Van den Bossche. J, Wagner C, De Schouwer P, Hugo N, Van De Vyvere M. Determination of iron metabolism- related reference values in a healthy adult population. Clin Chem. 2001; 47(8):1465- 7

25. Test principles for soluble transferrin receptor by Biovendor. https:/www.biovendor.com/file/5074/PDS_06_sTfR_ ENG.004.A.pdf date accessed online:21/7/2014.

26. Simek M, Remkova A, Kratochvilova H. Serum transferrin receptor in diagnosis of iron deficiency. Bratisl Lek Listy. 2002; 103(12): 449-53.

27. Von Schmiesing A, Schmidt SA, Krater W et al. Determination of reference values for the soluble transferrin receptor(sTfR) on a cross sectional population sample. Clin Lab. 2009; 55(5-6): 193-9.

28. Raya G, Henny J, Steinmetz J, Herbeth B, Siest G. Soluble transferrin receptor(sTfR): Biological variations and reference limits. Clin Chem Lab Med. 2001; 39(11): 1162-8.

29. Tijanic I, Vucic M, Golubovic LM. The significance of soluble transferrin receptors I diagnosing iron deficiency anemia. Revista Romana de Medicina de Laborator. 2015;23: 275-83

30. Jong Weon Choi, Soo Hwan Pai, Moon Wham Im, Soon Ki Kim. Change in transferrin receptor concentration with age. Clin Chem: 1999; 45(9)

31. Vernet M, Doyen C. Assessment of iron status with a new fully automated assay for transferrin receptor in human serum. Clin Chem Lab Med: CCLM/FESCC. 2000; 38(5): 437-42.

32. HA Huebers, Y Beguin, P Pootrakul, D Einsparh, CA Finch. Intact transferrin receptors in human plasma and their relation to erythropoiesis. Blood. 1990; 75: 102-107

*Corresponding author:

Dr Chilota Efobi, Department of Haematology, Chukwuemeka Odumegwu Ojukwu University, Akwa Campus, Awka, Anambra State, Nigeria.

Phone: +91 7030765610

Email: chylowb@yahoo.com

Date of Submission : 30.12.2016

Date of Acceptance : 06.03.2017

Financial or other Competing Interests: None.

Date of Publication : 31.05.2017 